\title{
Diffuse Large B-Cell Lymphoma
}

National Cancer Institute

\section{Source}

National Cancer Institute. Diffuse Large B-Cell Lymphoma. NCI Thesaurus. Code C8851.

A non-Hodg kin lymphoma characterized by a diffuse proliferation of predominantly large neoplastic B lymphocytes. It is the most frequently seen type of non-Hodgkin lymphoma, representing 30\%-40\% of the cases. Morphologic variants include centroblastic lymphoma, immunoblastic lymphoma, and anaplastic lymphoma. Subtypes/entities include T-cell/histiocyte rich large B-cell lymphoma, primary diffuse large B-cell lymphoma of the central nervous system, plasmablastic lymphoma, primary cutaneous diffuse large B-cell lymphoma, leg type, and ALK-positive large B-cell lymphoma. 